\section{Comecon joint research under strain because of complexity}

\section{London}

A remarkably frank account of impediments encountered by Comecon countries in their plan for joint research and development is emerging in the wake of last month's meeting of the party secretaries in Sofia. According to Pravda, one of the most serious difficulties is that European Comecon countries have set up separate research and development facilities, especially in microelectronics.

This admission is significant because the objective of the "comprehensive programme for scientific and technical progress", launched in December 1985, was to pool technical resources in five key areas (microelectronics, automation, nuclear power, new structural materials and biotechnology).

Earlier in the year, Comecon secretary Vyasheslav Sychev was saying that the programme had started slowly because of its complexity (more than 1,500 research institutes are involved) and the legal and cultural differences between Comecon countries. But even before the launching of the programme, Comecon has been stressing the benefits of planned diversification of research and the avoidance of duplication.

It has been known for some time that particular countries have been unhappy with some conclusions of the "fraternal discussions" by which decisions on the sharing of the burden of research and development are supposed to be made.

Bulgaria was thus given special help to developing its computer industry, while East Germany was dismayed at having to switch to new Comecon standards, threatening to make it diverge from West German standards (and was consoled by being made the host for the Comecon Standards Commission, allowing it to limit the divergence).

Cooperation with Comecon is most familiarly represented by joint projects in space and nuclear research, although the high magnetic field/low temperature institute at Wroclaw may be a more interesting example of joint research. But specific and often bilateral collaboration in industry and agriculture have not always achieved their goals.

Thus Dr Stoyan Markov, president of the Bulgarian State Committee for Science and Technology, has said in an interview in the Slovak Pravda that many cooperation projects have been illchosen, have involved obsolete technology and have brought no real benefit to those concerned.

Comecon cooperation with its three less developed members (Cuba, Mongolia and Vietnam) raises special problems taken up at Sofia. Mongolia has been helped in the past by geological surveys, followed by strip-mining of the ore located, but is now asking for help with biotechnology.

Cuba has been helped chiefly with
Munich

A US commercial surrogate motherhood company is on a collision course with the West German authorities after opening an office in Frankfurt on 1 October.

The company, United Families International (UFI), was given notice on 9 October by Frankfurt city officials that it is in violation of West Germany's adoption law and is subject to fines of up to DM 50,000 .

But UFI representative Franklin Torch disagrees, saying that "West Germany is powerless to challenge" his company, which signs no contracts with the wouldbe parents but rather refers them to its parent company in the United States, the Infertility Center of Michigan (ICM).

ICM is the company whose New York office organized the adoption of 'Baby $M$ ' in New Jersey in 1986. The New Jersey courts set a US precedent when they awarded custody of Baby $M$ to the biological father and his wife despite the protests of the surrogate mother who bore the child. (That ruling has been appealed against.) UFI is believed to be the first surrogate motherhood company to open an office in Western Europe.

The West German Ministry of Justice spoke out strongly against the offer of "mothers for hire" to childless West German couples. Spokesman Jürgen Schmid called it "the purest form of trafficking in human beings" and predicted that UFI would never win in a West German court. He said that only state-run or state-approved adoption agencies are allowed to operate in West Germany. Furthermore, West German adoption law would award a baby borne to a surrogate mother to the surrogate, even if she had signed a contract to turn the baby over to the biological father and his wife. Such contracts are considered null and void in West Germany.

Changes in the West German adoption laws are planned to protect the rights of the surrogate mother even more thoroughly.If approved by the Bundestag, the changes would give the baby to the surrogate even when both sperm and egg, fertilized in vitro, come from the would-be adoptive parents. resource exploitation and electric power generation, and while the industrial members of Comecon have helped with the construction of more than 300 manufacturing plants in Vietnam (some of them enterprises destroyed in South Vietnam during the civil war), there are now complaints that some of the machinery supplied is unsuitable for the tropical conditions.

\title{
West German ructions over US surrogacy company
}

UFI reports that it has received several requests for information. The whole process, including medical and legal fees, normally costs $\$ 30,000$. ICM has served as the go-between in the adoption of 184 surrogate babies so far and did $\$ 700,000$ worth of business in 1986 .

Although ICM customers have come from as far away as France, Italy, Israel, Greece and Australia, all of the surrogate mothers so far have been from the United States or Canada. Each surrogate mother receives payment of $\$ 10,000$ for bearing a child.

Torch reported that "three or four" West German couples have already adopted babies through ICM in the United States.Apparently these cases have not come to the attention of the Justice Ministry, whose spokesman said West Germany would categorically deny adoption papers to couples so "pathological" as to want to adopt a baby in this manner.

ICM's international business may expand even if West German authorities succeed in closing UFI, which will surely not go down without a fight. The publicity surrounding UFI's opening may have been enough free advertising to last for years. And it is questionable whether West German authorities could determine that newly adopted babies had been born by this procedure, as it is possible for the adoptive parents to obtain a second birth certificate for the baby citing the wife as the baby's mother. Steven Dickman Mars trip far off

\section{London}

No manned trip to Mars can be expected before the turn of the century, according to Cosmonaut Aleksandr Serebrov.

Addressing a press conference in Budapest to mark the 30th anniversary of the Soviet satellite Sputnik-1, he said that no "official decision" about a future Mars mission had yet been made, but that tentative longer-range plans were being drawn up for an international mission. Shortrange plans, to the end of the century, would "create the conditions" for a manned flight to Mars. V.R. 